\title{
Endodontics
}

\section{In vitro antimicrobial activity of different gutta-percha points and calcium hydroxide pastes}

\author{
Atividade antimicrobiana in vitro de diferentes \\ composições de cones de guta-percha e pastas \\ de hidróxido de cálcio
}

\section{Juliane Maria Guerreiro Tanomaru(a) Fernanda Geraldes Pappen ${ }^{(b)}$ Mário Tanomaru Filho(c) Denise Madalena Palomari Spolidorio(d) Izabel Yoko Ito(e)}

(a) Assistant Professor of Therapeutics; (b) PhD Student; (c)Associate Professor of Endodontics; (d) Assistant Professor of Pathology - School of Dentistry of Araraquara, State University of São Paulo.

(e) PhD, Full Professor of Microbiology, School of Pharmacy of Ribeirão Preto, University of São Paulo.

\section{Corresponding author: \\ Juliane Maria Guerreiro Tanomaru Rua Expedicionários do Brasil, 2030 - Apto. 122 - Araraquara - SP - Brazil CEP: $14801-360$ \\ E-mail: jutanomaru@uol.com.br}

Received for publication on Sep 08, 2005 Sent for alterations on Jul 03, 2006

Accepted for publication on Sep 25, 2006

\begin{abstract}
The aim of this study was to evaluate the antimicrobial activity of different trademarks and compositions of gutta-percha points and calcium hydroxide pastes used in endodontic therapy. The evaluated material consisted of gutta-percha points containing calcium hydroxide $\left(\right.$ Roeko $\left.^{\mathrm{TM}}\right)$, gutta-percha points containing chlorhexidine $\left(\right.$ Roeko $\left.^{\mathrm{TM}}\right)$, two convencional gutta-percha points (Endo Points ${ }^{\mathrm{TM}}$ and Roeko ${ }^{\mathrm{TM}}$ ) and two calcium hydroxide pastes (Calen ${ }^{\mathrm{TM}}$ and Calen/PMCC ${ }^{\mathrm{TM}}$ ). Antimicrobial tests included five species of microorganisms: Escherichia coli (ATCC10538), Staphylococcus epidermidis (ATCC12228), Staphylococcus aureus (ATCC6538), Pseudomonas aeruginosa (ATCC27853), and Micrococcus luteus (ATCC9341). The Agar difusion method was employed. The plates were kept at room temperature for $2 \mathrm{~h}$ for prediffusion and then incubated at $37^{\circ} \mathrm{C}$ for $24 \mathrm{~h}$. The triphenyltetrazolium chloride gel was added for optimization and the zones of inhibition were measured. Statistical evaluation was carried out using analysis of variance and Tukey Test. The obtained results showed that all microbial species used in the study were inhibited by the gutta-percha points containing chlorhexidine and by the calcium hydroxide pastes $\left(\mathrm{Calen}^{\mathrm{TM}}\right.$ and Calen/PMCC $\left.{ }^{\mathrm{TM}}\right)$, with similar results $(p>0.05)$. No antimicrobial activity was observed for the other groups. It was concluded that the gutta-percha points containing chlorhexidine presented antimicrobial activity, whereas the gutta-percha points containing calcium hydroxide did not.
\end{abstract}

Descriptors: Gutta-percha; Microbiology; Calcium hydroxide; Chlorhexidine.

Resumo: O objetivo deste estudo foi a avaliação da atividade antimicrobiana de diferentes marcas e composições de cones de guta-percha e pastas à base de hidróxido de cálcio utilizados em endodontia. Os materiais avaliados foram: cones de guta-percha contendo hidróxido de cálcio (Roeko ${ }^{\mathrm{TM}}$ ), cones de guta-percha contendo clorexidina (Ro$\left.\mathrm{eko}^{\mathrm{TM}}\right)$, duas marcas de cones de guta-percha (Endo Points ${ }^{\mathrm{TM}}$ e Roeko ${ }^{\mathrm{TM}}$ ) e duas pastas à base de hidróxido de cálcio (Calen ${ }^{\mathrm{TM}}$ e Calen/PMCC ${ }^{\mathrm{TM}}$ ). Os testes antimicrobianos incluíram 5 espécies de microrganismos: Escherichia coli (ATCC10538), Staphylococcus epidermidis (ATCC12228), Staphylococcus aureus (ATCC6538), Psendomonas aeruginosa (ATCC27853) e Micrococcus luteus (ATCC9341). O método empregado foi o de difusão em Ágar. As placas foram mantidas em temperatura ambiente por 2 horas para pré-difusão e então incubadas a $37^{\circ} \mathrm{C}$ por 24 horas. O gel de cloreto de trifeniltetrazólio foi acrescentado para otimização e as zonas de inibição foram medidas. A análise estatística foi realizada pela análise de variância e pelo teste de Tukey. Os resultados obtidos demonstraram que todas as espécies microbianas usadas foram inibidas pelos cones de guta-percha com clorexidina e pelas pastas à base de hidróxido de cálcio $\left(\mathrm{Calen}^{\mathrm{TM}}\right.$ e Calen/PMCC ${ }^{\mathrm{TM}}$ ), com resultados similares entre os materiais ( $\left.\mathrm{p}>0.05\right)$. Nenhuma atividade antimicrobiana foi observada para os demais grupos. Concluiu-se que os cones de gutapercha com clorexidina apresentaram atividade antimicrobiana, enquanto os cones com hidróxido de cálcio não demonstraram esta propriedade.

Descritores: Guta-percha; Microbiologia; Hidróxido de cálcio; Clorexidina. 


\section{Introduction}

The success of endodontic therapy of non-vital teeth is directly related to the elimination of root canal infection. Besides the cleaning effect of biomechanical preparation, further means such as intracanal medication and the use of filling materials with antimicrobial and sealing properties are of essential importance. . $^{2,8,11,14,18}$

Calcium hydroxide pastes, commonly used as intracanal medication, have presented antimicrobial action and ability to inactivate endotoxins which facilitate the healing process of periapical tissues. , $^{1,9,19,20}$

Chlorhexidine, used as an irrigating solution, may present substantivity, ${ }^{16,17,21}$ has antimicrobial action and is able to inhibit most endodontic bacteria. ${ }^{1,3,4,10,13,17}$

With the aim of providing fuller antimicrobial action, gutta-percha points have been manufactured including several substances such as iodoform, chlorhexidine and calcium hydroxide. The antimicrobial effect of gutta-percha points containing calcium hydroxide was evaluated by Podbielski et al. ${ }^{12}$ (2000). When compared to conventional gutta-percha points, the points containing calcium hydroxide showed greater antimicrobial action against Enterococcus faecalis, Porphyromonas gingivalis, and Streptococcus intermedius.

Barthel et al. ${ }^{1}$ (2002) evaluated the antimicrobial action of gutta-percha points containing chlorhexidine or calcium hydroxide when compared to chlorhexidine gel and to calcium hydroxide paste. Conventional gutta-percha points showed smaller microbial inhibition.

The aim of this study was to evaluate in vitro the antimicrobial activity of conventional gutta-percha points, points containing calcium hydroxide or chlorhexidine, and two calcium hydroxide pastes.

\section{Material and Methods}

The evaluated materials were: calcium hydroxide gutta-percha points (Roeko Gmbh + Co., Langenau, Baden-Württemberg, Germany), gutta-percha points containing chlorhexidine (Roeko Gmbh + Co., Langenau, Baden-Württemberg, Germany), two brands of conventional gutta-percha points (Roeko Gmbh + Co., Langenau, Baden-Württemberg, Germany and
Endo Points Ind. e Com. Ltda., Rio de Janeiro, RJ, Brazil) and two calcium hydroxide based pastes (Calen and Calen/PMCC - S.S.White, Rio de Janeiro, RJ, Brazil). The morphotype and origin of the strains used as indicators of antimicrobial activity are presented on Table 1.

The inocula were obtained by suspending in saline the strains cultivated in $\mathrm{MHb}$ (Mueller-Hinton Broth - Difco ${ }^{\mathrm{TM}}$, Detroit, MI, USA), to a density of 0.5 on the Mc Farland scale.

Tests were performed using the plate diffusion method with $\mathrm{MH}$ media (Mueller-Hinton Medium - Difco ${ }^{\mathrm{TM}}$, Detroit, MI, USA) which was cooled to about $50^{\circ} \mathrm{C}$, inoculated, and poured into 20 x 100 mm sterilized Petri dishes.

Paper points were involved with Calen $^{\mathrm{TM}}$ or Calen/PMCC ${ }^{\mathrm{TM}}$ pastes (S.S.White, Rio de Janeiro, RJ, Brazil) and immediately applied. Afterwards, the tested cones were placed at equidistant points. The test was made in triplicate. Plates were kept at room temperature for two hours, so pre-diffusion of the material could occur, and then they were incubated at $37^{\circ} \mathrm{C}$ for 24 hours.

After the incubation period, amounts of $5 \mathrm{ml}$ of $1 \%$ TTC gel prepared with agar $\left(\mathrm{Difco}^{\mathrm{TM}}\right.$, Detroit, MI, USA) and $0.05 \%$ of triphenyltetrazolium chloride (TTC, Sigma ${ }^{\mathrm{TM}}$, St. Louis, MO, USA) were added to optimize the plates. After solidification occurred, they were incubated at $37^{\circ} \mathrm{C}$ for 30 minutes so the color could be developed to facilitate the measurement.

The biggest inhibition zone was measured with a millimeter ruler. Statistical evaluation was carried out using analysis of variance and Tukey Test, with a level of significance at $5 \%(\mathrm{p}<0.05)$.

Table 1 - Strains used as indicators of antimicrobiological activity - origin and morphotype.

\begin{tabular}{l|c|c}
\hline \multicolumn{1}{c|}{ Microrganisms } & Origin & Morphotype \\
\hline Micrococcus luteus & ATCC 9341 & $\mathrm{cg}+$ \\
\hline Staphylococcus aureus & ATCC 6538 & $\mathrm{cg}+$ \\
\hline Staphylococcus epidermidis & ATCC 12228 & $\mathrm{cg}+$ \\
\hline Escherichia coli & ATCC 10538 & $\mathrm{bg}-$ \\
\hline Pseudomonas aeruginosa & ATCC 27853 & $\mathrm{bg}-$ \\
\hline
\end{tabular}

cg +: Gram-positive cocci; bg-: Gram-negative bacilli. 


\section{Results}

Figure 1 shows the inhibition zone after the use of the TTC gel. Table 2 shows the means and standard deviations of the diameter of the inhibition zone in millimeters. The results showed that all microbial species used in the study were inhibited by the gutta-percha points containing chlorhexidine and by the calcium hydroxide pastes $\left(\mathrm{Calen}^{\mathrm{TM}}\right.$ and Calen/PMCC $\left.{ }^{\mathrm{TM}}\right)$, with similar results $(\mathrm{p}>0.05)$. No antimicrobial activity was observed in the other groups.

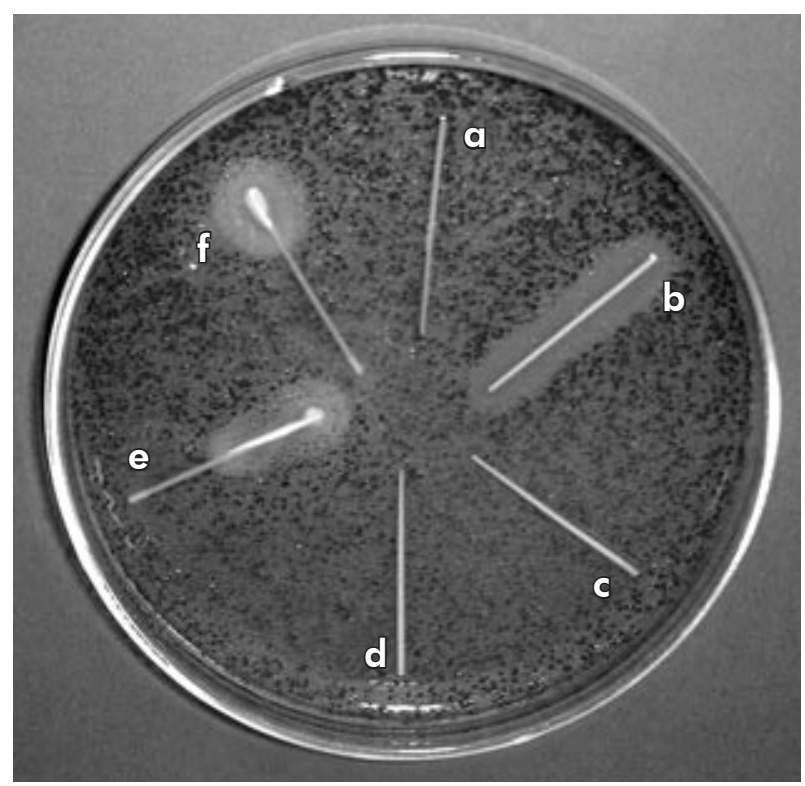

Figure 1 - Inhibition zone after optimization of the culture medium with TTC gel for Escherichia coli. a: $\mathrm{Ca}(\mathrm{OH})_{2}$ Point; b: Chlorhexidine gutta-percha point; c: Conventional Roeko gutta-percha point; $\mathbf{d}$ : Conventional Endo Points gutta-percha point; e: Paper point + Calen paste; f: Paper point + Calen/PMCC paste.

\section{Discussion}

The agar diffusion method which was used in the present study is one of the most commonly employed methods among those that evaluate antimicrobial activity. ${ }^{1,5,715,22}$ However, the following peculiarities should be taken into consideration when applying such method: the contact between the tested material and the agar; the weight, size, and molecular shape of the antimicrobial agent; the loading and concentration of the tested material; the agar gel texture; and the ionic concentration of the medium. All these are relevant factors to the material diffusion in agar. Some other factors that may limit the dynamics and variability of agar diffusion tests include the control and standardization of inoculum density, the moment at which the results are read, the choice of agar, the incubation temperature of the plates, and the reading of the ihnibition zone.

The lack of standardization of these factors may be considered the main cause of the difference between the present results and those found in comparative studies about antimicrobial properties of endodontic materials. ${ }^{5}$

Because it was an in vitro experiment, in addition to the standardization of the above mentioned factors, it was possible to eliminate several in vivo variables.

The pre-incubation, which consisted of maintaining the culture media innoculated for about 2 hours at room temperature, ${ }^{6}$ was an important factor to evince the antimicrobial activity of the calcium hydroxide pastes. Those results were in accordance with the results found by Leonardo et al. ${ }^{6}$ (2000), who employed similar methodology. However, no antimicrobial activity for the gutta-percha points containing calcium hydroxide was observed.

Table 2 - Means and standard deviations of the inhibition zones (in millimeters).

\begin{tabular}{|c|c|c|c|c|c|}
\hline Material Microorganism & M. luteus & S. aureus & S. epidermidis & E. coli & P. aeruginosa \\
\hline $\mathrm{Ca}(\mathrm{OH})_{2}$ gutta-percha point & 0 & 0 & 0 & 0 & 0 \\
\hline Chlorhexidine gutta-percha point & $8.5 \pm 1.0$ & $5.5 \pm 1.0$ & $6.0 \pm 0$ & $8.5 \pm 0.5$ & $7.0 \pm 0.5$ \\
\hline Conventional a gutta-percha point & 0 & 0 & 0 & 0 & 0 \\
\hline Conventional b gutta-percha point & 0 & 0 & 0 & 0 & 0 \\
\hline Paper point + Calen paste & $6.5 \pm 1.5$ & $6.0 \pm 0.5$ & $6.0 \pm 0.5$ & $6.0 \pm 0.5$ & $6.0 \pm 0$ \\
\hline Paper point + Calen/PMCC paste & $8.5 \pm 1.0$ & $5.5 \pm 1.0$ & $7.5 \pm 1.0$ & $7.0 \pm 1.0$ & $6.0 \pm 0$ \\
\hline
\end{tabular}

Means of triplicate measurements. a) Roeko Gmbh + Co., Langenau, Germany. b) Endo Points Ind. e Com. Ltda., Rio de Janeiro, Brazil. 
The optimization of the culture media with $1 \%$ TTC gel after the incubation period aimed at differentiating the growing bacterial colonies. This was a meaningful factor to the employed methodology. This procedure, through the changing in the medium color, facilitated the observation of the bacteria growth inhibition zone which could easily be misinterpreted with the material diffusion zone.

Barthel et al. ${ }^{1}$ (2002) and Lenet et al. ${ }^{5}$ (2000) showed that gutta-percha points containing chlorhexidine have a smaller antimicrobial effect than chlorhexidine in other vehicles. In the present study, however, those points were able to provide inhibition zones similar to those provided by the Calen ${ }^{\mathrm{TM}}$ and Calen/PMCC ${ }^{\mathrm{TM}}$ calcium hydroxide pastes. On the other hand, Lui et al. ${ }^{8}$ (2004), when evaluating gutta-percha points containing chlorhexidine in vitro, did not find enough antimicrobial activity against $E$. faecalis inside infected dentine tubules. Szep et al. ${ }^{16}$ (2003) found greater toxicity in gutta-percha points containing chlorhexidine than in calcium hydroxide or conventional gutta-percha points.

The antimicrobial action of materials containing calcium hydroxide depends on calcium hydroxide ionization and on the release of hydroxil ions that promote an increase in the medium $\mathrm{pH}$ and its maintenance. Hydroxil ions also have some action

\section{References}

1. Barthel CR, Zimmer S, Zilliges S, Schiller R, Gobel UB, Roulet JF. In situ antimicrobial effectiveness of chlorhexidine and calcium hydroxide: gel and paste versus gutta-percha points. J Endod. 2002;28(6):427-30.

2. Byström A, Sundqvist G. Bacteriologic evaluation of the efficacy of mechanical root canal instrumentation in endodontic therapy. Scand J Dent Res. 1981;89(4):321-8.

3. Georgopoulou M, Kontakiotis E, Nakou M. In vitro evaluation of the effectiveness of calcium hydroxide and paramonochlorophenol on anaerobic bacteria from the root canal. Endod Dent Traumatol. 1993;9(6):249-53.

4. Heling I, Steinberg D, Kenig S, Gavrilovich I, Sela MN, Friedman M. Efficacy of a sustained-release device containing chlorhexidine and $\mathrm{Ca}(\mathrm{OH})_{2}$ in preventing secondary infection of dentinal tubules. Int Endod J. 1992;25(1):20-4.

5. Lenet B, Komorowski R, Wu X, Huang J, Grad H, Lawrence $\mathrm{HP}$ et al. Antimicrobial substantivity of bovine root dentin on bacterial cells through the destruction of insaturated fatty acids or phospholipids of the bacterial citoplasmatic membrane. ${ }^{12}$

Evaluation of the antimicrobial activity of materials containing calcium hydroxide in solid media presents some difficulties. The possible buffering of calcium hydroxide $\mathrm{pH}$ in this medium can harm its action. The antimicrobial effect of calcium hydroxide is directly related to its capacity of diffusion and alcalinization in the culture medium which can be decreased by the low solubility of the calcium hydroxide cointained in the point. ${ }^{1}$ This fact could explain the results obtained in this study that show that the gutta-percha points containing calcium hydroxide did not present antimicrobial activity on the tested strains.

\section{Conclusions}

1. The gutta-percha points containing chlorhexidine $\left(\right.$ Roeko $\left.^{\mathrm{TM}}\right)$ and the calcium hydroxide pastes (Calen $^{\mathrm{TM}}$ and Calen/PMCC ${ }^{\mathrm{TM}}$ ) presented in vitro antimicrobial activity against all of the strains used in this study.

2. The calcium hydroxide points $\left(\right.$ Roeko $\left.^{\mathrm{TM}}\right)$ and the conventional gutta-percha points (Endo Points ${ }^{\mathrm{TM}}$ and Roeko ${ }^{\mathrm{TM}}$ ) did not present antimicrobial activity.

exposed to different chlorhexidine delivery vehicles. J Endod. 2000;26(11):652-5.

6. Leonardo MR, da Silva LA, Tanomaru-Filho M, Bonifacio KC, Ito IY. In vitro evaluation of antimicrobial activity of sealers and pastes used in endodontics. J Endod. 2000;26(7):391-4.

7. Leonardo MR, Tanomaru Filho M, Silva LA, Nelson Filho $\mathrm{P}$, Bonifácio KC, Ito IY. In vivo antimicrobial activity of $2 \%$ chlorhexidine used as a root canal irrigating solution. J Endod. 1999;25(3):167-71.

8. Lui JN, Sae-Lim V, Song KP, Chen NN. In vitro antimicrobial effect of chlorhexidine-impregnated gutta percha points on Enterococcus faecalis. Int Endod J. 2004;37(2):105-13.

9. Moller AJ. Microbiological examination of root canals and periapical tissues of human teeth. Methodological studies. Odontol Tidskr. 1966;74(5):Suppl:1-380.

10. Ohara PK, Torabinejad M, Kettering JD. Antibacterial effects of various endodontic irrigants on selected anaerobic bacteria. Endod Dent Traumatol. 1993;9(3):95-100. 
11. Orstavik D. Antibacterial properties of root canal sealers, cements and pastes. Int Endod J. 1981;14(2):125-33.

12. Podbielski A, Boeckh C, Haller B. Growth inhibitory activity of gutta-percha points containing root canal medications on common endodontic bacterial pathogens as determined by an optimized quantitative in vitro assay. J Endod. 2000;26(7):398-403.

13. Rubinn E, Farber JL. Patologia. Rio de Janeiro: Interlivros; 1990.

14. Siqueira JF Jr. Endodontic infections: concepts, paradigms, and perspectives. Oral Surg Oral Med Oral Pathol Oral Radiol Endod. 2002;94(3):281-93.

15. Siqueira JF Jr, de Uzeda M. Intracanal medicaments: evaluation of the antibacterial effects of chlorhexidine, metronidazole, and calcium hydroxide associated with three vehicles. J Endod. 1997;23(3):167-9.

16. Szep S, Grumann L, Ronge K, Schriever A, Schultze M, Heidemann D. In vitro cytotoxicity of medicated and nonmedicated gutta-percha points in cultures of gingival fibroblasts. J Endod. 2003;29(1):36-40.
17. Tanomaru JM, Leonardo MR, Tanomaru Filho M, Bonetti Filho I, Silva LA. Effect of different irrigation solutions and calcium hydroxide on bacterial LPS. Int Endod J. 2003;36(11):733-9.

18. Tanomaru Filho M, Leonardo MR, Silva LA. Effect of irrigating solution and calcium hydroxide root canal dressing on the repair of apical and periapical tissues of teeth with periapical lesion. J Endod. 2002;28(4):295-9.

19. Tobias RS. Antibacterial properties of dental restorative materials: a review. Int Endod J. 1988;21(2):155-60.

20. Tronstad L, Barnett F, Riso K, Slots J. Extraradicular endodontic infections. Endod Dental Traumatol. 1987;3(2):86-90.

21. White RR, Hays GL, Janer LR. Residual antimicrobial activity after canal irrigation with chlorhexidine. J Endod. 1997;23(4):229-31.

22. Yesilsoy C, Whitaker E, Cleveland D, Phillips E, Trope M. Antimicrobial and toxic effects of established and potential root canal irrigants. J Endod. 1995;21(8):513-5. 